\title{
Altered Calcium Handling in Peripheral Nerve Terminals and Blood Vessels in Spontaneously Hypertensive Rats
}

\author{
Naomi Iwane, Yumi Koike, Takuzo Hano \\ Medical Education and Population-Based Medicine, Wakayama Medical University, Wakayama, Japan \\ Email: hanotaku@wakayama-med.ac.jp
}

How to cite this paper: Iwane, N., Koike, Y. and Hano, T. (2017) Altered Calcium Handling in Peripheral Nerve Terminals and Blood Vessels in Spontaneously Hypertensive Rats. Health, 9, 317-322. https://doi.org/10.4236/health.2017.92022

Received: January 24, 2017

Accepted: February 18, 2017

Published: February 21, 2017

Copyright (C) 2017 by authors and Scientific Research Publishing Inc. This work is licensed under the Creative Commons Attribution International License (CC BY 4.0).

http://creativecommons.org/licenses/by/4.0/

(c) (i) Open Access

\begin{abstract}
The present study was designed to clarify the roles of N-type and P/Q-type calcium channels in the increased sympathetic activity of spontaneously hypertensive rats (SHR/Izm). We also tested in SHR/Izm the contribution to increased vascular tone of $\alpha_{1 \mathrm{~A}}$ adrenoceptor-linked L-type calcium channels and $\alpha 1 \mathrm{~B}$ receptor-mediated calcium mobilization from the sarcoplasmic reticulum. Methods: Six-week-old SHR/Izm and Wistar-Kyoto rats (WKY/Izm) were used. A superior mesenteric arterial preparation was electrically stimulated before and after treatment with $\omega$-conotoxin GVIa (N-type calcium channel blocker [CgTX]) and $\omega$-agatoxinIVa (P/Q-type calcium channel blocker [AgaTX]). Pressor response to norepinephrine was measured before and after treatment with the $\alpha_{1 \mathrm{~A}}$ blocker WB-4101 and the $\alpha_{1 \mathrm{~B}}$ blocker chloroethyl clonidine (CEC). To determine the intracellular calcium store size, the effects of ryanodine on pressor response and caffeine-induced vascular contraction were also tested. Results: Norepinephrine overflow evoked by electrical stimulation was increased in SHR/Izm. CgTX but not AgaTX suppressed the increased NE overflow in SHR/Izm. WB-4101 suppressed the pressor response to norepinephrine in SHR/Izm but not WKY/Izm rats. CEC had no effects on pressor response to norepinephrine in both types of rats. Caffeine-induced contraction to a high potassium-induced maximal contraction ratio was reduced in SHR/Izm. The effect of ryanodine on pressor response was reduced in SHR/Izm. Conclusion: N-type calcium channels but not P/Q-type calcium channels play an important role in the increased sympathetic tone in SHR/ Izm. Although $\alpha_{1 \mathrm{~A}}$ adrenoceptor-linked L-type calcium channels contribute to the increased vascular tone, the intracellular calcium store size was reduced in SHR/Izm.
\end{abstract}

\section{Keywords}

Hypertension, Calcium, Sympathetic Nerve, Blood Vessel 


\section{Introduction}

In our previous studies, we reported that spontaneously hypertensive rats (SHRs) had high plasma norepinephrine (NE) levels [1], similar to hypertensive patients [2], and that young SHRs had increased NE overflow from nerve endings in the mesenteric arteries [3]. In a series of publication, mechanisms of hypertension of SHR were similar to essential hypertension and WKY strain was commonly used as normotensive controls. Calcium ions play a role in NE release from nerve terminals and vascular contraction. $\mathrm{N}$-type [4] and P/Q-type [5] calcium channels existed in nerve endings and initiated the neurotransmitter release. $\alpha_{1 \mathrm{~A}}$-adrenoceptor links L-type calcium channels of vascular beds and $\alpha_{1 \mathrm{~B}^{-}}$ adrenoceptor linked phospholipase $\mathrm{C}$, which stimulate calcium mobilization from intracellular calcium store. Calcium antagonists are also major anti-hypertensive drugs and their magnitude of depressor effect is higher in hypertensive patients than in normal individuals. However, the precise role of calcium in hypertension is unclear.

The present study was conducted to clarify the roles of N-type and P/Q-type calcium channels in the increased sympathetic activity of SHRs. In addition, we tested in SHRs the contribution to the increased vascular tone of $\alpha_{1 \mathrm{~A}}$ adrenoceptor-linked L-type calcium channel and the extent of calcium mobilization from the smooth-surfaced endoplasmic reticulum, an intracellular calcium store.

\section{Methods}

\subsection{Animals and Protocols}

Six-week-old SHR/Izm and Wistar-Kyoto rats (WKY/Izm) were used. Male SHR/Izm strain rats were obtained from the Disease Model Cooperative Research Association and were housed under a 12-hour light/dark cycle. Animals were handled according to the institutional guidelines for animal research of Wakayama Medical University. An isolated mesenteric arterial preparation was made as previously reported [3]. Briefly, polyethylene tubes were inserted into the superior mesenteric artery and the mesenteric artery-intestine loop preparation was perfused with Krebs-Henseleit solution. The superior mesenteric arterial preparation was electrically stimulated $(10 \mathrm{~Hz}, 1 \mathrm{~ms}$ duration, supramaximal voltage) before and after treatment with $\omega$-conotoxinGVIa [6] [7] (N-type calcium channel blocker [CgTX]; $5 \times 10^{-9} \mathrm{M}$ ) and $\omega$-agatoxinIVa (P/Q-type calcium channel blocker [AgaTX [7]]; $\left.5 \times 10^{-11} \mathrm{M}\right)$. Pressor response to NE was measured before and after treatment with the $\alpha 1 \mathrm{~A}$ blocker WB-4101 [8] (WB; $10^{-9} \mathrm{M}$ ) and the $\alpha 1 \mathrm{~B}$ blocker chloroethylclonidine [9] (CEC; $5 \times 10^{-6} \mathrm{M}$ ). The dosages used were based on previous work [6] [7] [8] [9] [10] and preliminary studies. To determine the intracellular calcium store size, the effects of ryanodine [11] $\left(1 \times 10^{-5} \mathrm{M}\right)$ on pressor response to NE and caffeine [12] $(20 \mathrm{mM})$ induced vascular contraction were also tested. Perfusion pressure was measured by a pressure transducer (TR-200, Gulton Industries Inc.). NE overflow was measured by HPLC using an electrochemical detector. 


\subsection{Statistical Analysis}

Group differences in pressure response and NE overflow and their percent changes in both strains of rats were examined using independent t-tests. Differences between dose-dependent pressor responses and the effects of chemicals on pressor response were analyzed by two-way ANOVA. Differences were considered significant at $\mathrm{p}<0.05$.

\section{Results}

The blood pressure levels of SHR/Izm and WKY/Izm rats were $167 \pm 15 \mathrm{mmHg}$ and $139 \pm 8 \mathrm{mmHg}$, respectively. Pressor response and NE overflow evoked by electrical stimulation were increased in SHR/Izm $(n=6)$ compared with WKY/ Izm rats $(n=6)$ (pressor response: SHR/Izm, $35.9 \pm 3.2 \mathrm{mmHg}$ vs. WKY/Izm, $14.1 \pm 2.4 \mathrm{mmHg}$; NE overflow: SHR/Izm, $1.56 \pm 0.4 \mathrm{ng} / \mathrm{g}$ wet.wt vs. WKY/Izm, $0.65 \pm 0.1 \mathrm{ng} / \mathrm{g}$ wet.wt) (Figure 1).

CgTX significantly suppressed pressor response and NE overflow evoked by electrical stimulation in SHR/Izm $(n=6)$ compared with WKY/Izm rats $(n=6)$. The percent decrease in pressor response to electrical stimulation was higher in SHR/Izm $(-82.1 \% \pm 1.7 \%)$ than in WKY/Izm rats $(-65.4 \% \pm 0.8 \%, \mathrm{p}<0.05)$ and the percent decrease in NE overflow showed a similar trend in SHR/Izm $(-79.9 \% \pm 1.5 \%)$ and WKY/Izm rats $(-68.4 \% \pm 0.7 \%, \mathrm{p}<0.05)$.

In contrast, AgaTX more markedly suppressed the pressor response and NE overflow evoked by electrical stimulation in WKY/Izm rats $(n=6)$ compared with SHR/Izm $(\mathrm{n}=6)$. The percent decrease in pressor response to electrical stimulation was lower in SHR/Izm $(-20.3 \% \pm 1.0 \%)$ than in WKY/Izm rats $(-53.1 \% \pm 0.8 \%, \mathrm{p}<0.05)$ and the percent decrease in NE overflow was $-5.5 \% \pm$ $1.0 \%$ in SHR/Izm and $-50.4 \% \pm 0.7 \%$ in WKY/Izm rats $(\mathrm{p}<0.05)$ (Figure 2 ).

Pressor response to NE was increased in SHR/Izm $(\mathrm{n}=6)$ (NE 0.5 micro g, $39.0 \pm 0.9 \mathrm{mmHg}$; NE 1.0 micro g, $60.7 \pm 7.5 \mathrm{mmHg}$ ) compared with WKY/Izm rats $(\mathrm{n}=6)(\mathrm{NE} 0.5$ micro g, $13.1 \pm 3.1 \mathrm{mmHg}$; NE 1.0 micro g, $23.0 \pm 3.1$ $\mathrm{mmHg}, \mathrm{p}<0.01)$. WB-4101 suppressed pressor response to NE in SHR/Izm ( $\mathrm{n}=$

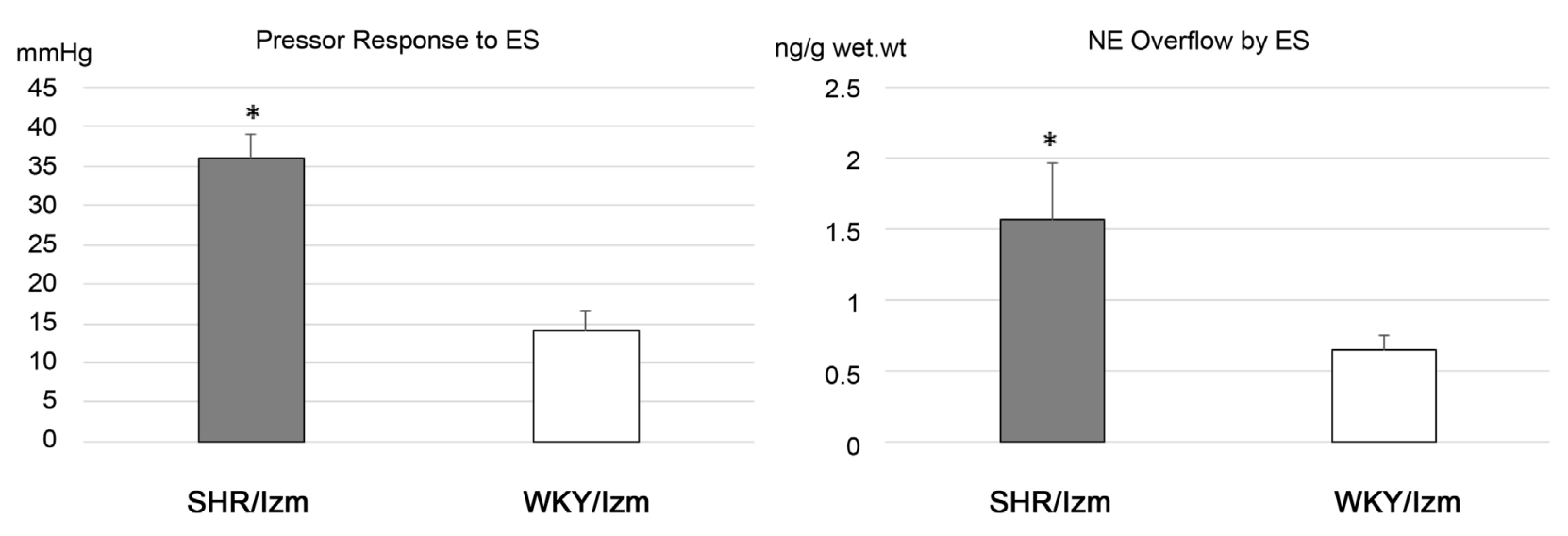

Figure 1. Pressor response and NE overflow evoked by electrical stimulation were increased in SHR/Izm compared with WKY/Izm rats $\left({ }^{*} \mathrm{p}<0.05\right)$. 


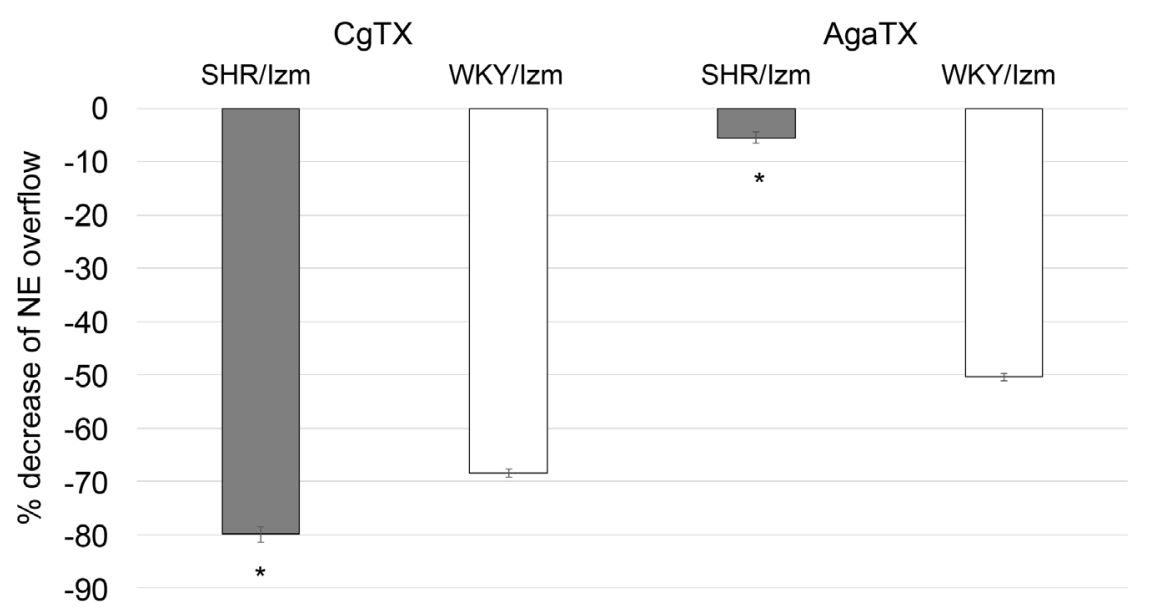

Figure 2. Percent decrease in NE overflow with $\omega$-conotoxin (N-type calcium channel blocker, CgTX) and $\omega$-agatoxin (P/Q-type calcium channel blocker, AgaTX) in SHR/Izm and WKY/Izm rats. The effect of CgTX on NE overflow was significantly greater in SHR/Izm than in WKY/Izm rats (left panel, ${ }^{*} \mathrm{p}<0.05$ ). AgaTX suppressed NE overflow to a lesser extent in SHR/Izm than in WKY/Izm rats $\left({ }^{*} \mathrm{p}<0.05\right)$.

6) (NE 0.5 micro g, $-35 \% \pm 2 \%$; NE 1.0 micro g, $-53 \% \pm 2 \%$ ) but not in WKY/ Izm rats $(\mathrm{n}=6)$ (NE 0.5 micro g, $-78 \% \pm 8 \%$; NE 1.0 micro g, $-78 \% \pm 12 \%, \mathrm{p}<$ 0.01). CEC showed no effects on pressor response to NE in both strains of rats (SHR [n = 6]: NE 0.5 micro g, $-37 \% \pm 4 \%$; NE 1.0 micro g, $-41 \% \pm 1 \%$; WKY [ $\mathrm{n}=$ 6]: NE 0.5 micro g, $-45 \% \pm 5 \%$; NE 1.0 micro g, $-41 \% \pm 6 \%$ ).

Caffeine $(20 \mathrm{mM})$-induced contraction was $7.7 \pm 0.9 \mathrm{mmHg}$ in SHR/Izm ( $\mathrm{n}=$ 6) and $9.1 \pm 0.8 \mathrm{mmHg}$ in WKY/Izm rats $(\mathrm{n}=6)(\mathrm{p}<0.05)$. High potassium $(128 \mathrm{mM})$-induced maximal contraction was $45.5 \pm 6.3 \mathrm{mmHg}$ in SHR/Izm and $25.4 \pm 1.8 \mathrm{mmHg}$ in WKY/Izm rats $(\mathrm{p}<0.01)$. The ratio of caffeine-induced contraction to maximal contraction was lower in SHR/Izm $(0.17 \pm 0.01)$ than in WKY/Izm rats $(0.36 \pm 0.02)(\mathrm{p}<0.001)$ (Figure 3$)$.

Ryanodine significantly reduced NE-induced pressor response in both SHR/ $\operatorname{Izm}(\mathrm{n}=6)$ (from $47.9 \pm 3.5 \mathrm{mmHg}$ to $37.5+4.0 \mathrm{mmHg})$ and WKY/Izm rats $(\mathrm{n}=$ 6) (from $34.1 \pm 2.0 \mathrm{mmHg}$ to $22.3 \pm 5.7 \mathrm{mmHg}$ ) ( $\mathrm{p}<0.05$ ). In addition, the percent reduction in pressure response was $-13.8 \% \pm 2.7 \%$ in SHR/Izm and $-22.8 \% \pm$ $4.9 \%$ in WKY/Izm rats. The magnitude of the reduction in the pressure response was blunted in SHR/Izm compared with WKY/Izm rats $(\mathrm{p}<0.05)$.

\section{Discussion}

Our previous data show that isolated mesenteric nerve endings had increased NE release in young SHR/Izm [3] and that their hyperactive condition was suppressed more by calcium antagonist compared with normal rats [2]. In peripheral nerve endings, $\mathrm{N}$-type calcium channels play an important role in NE release, although P/Q-type calcium channels also participate. The magnitude of the relative contributions of N-type and P/Q-type channels in nerve terminals is unclear. In the present study, CgTX, N-type calcium antagonists, suppressed NE overflow more in SHR/Izm. In contrast, AgaTX, P/Q-type calcium antagonists, 


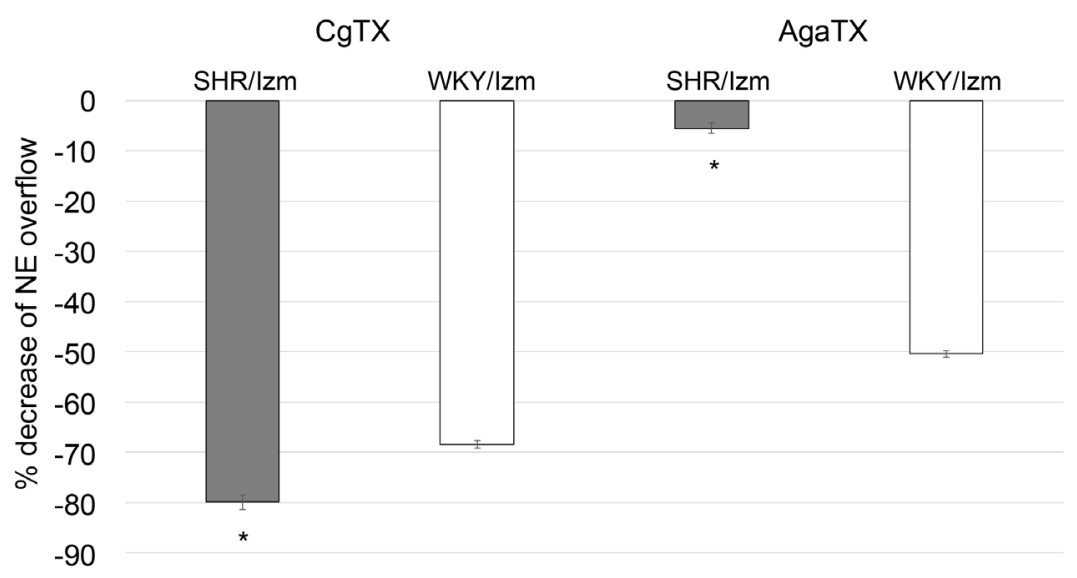

Figure 3. Ratio of caffeine-induced contraction to $\mathrm{KCl}$-induced maximal contraction. The ratio was significantly smaller in SHR/Izm than in WKY/Izm rats $\left({ }^{*} \mathrm{p}<0.001\right)$.

suppressed NE overflow more in WKY/Izm rats than in SHR/Izm. These results indicate that $\mathrm{N}$-type calcium channel contribute more to hyperactive nerve terminals of SHR/Izm and that P/Q-type calcium channel contribute less to NE release in nerve ending of hypertension.

NE promotes contraction of the vascular bed through $\alpha_{1 \mathrm{~A}}$-linked L-type calcium channels and $\alpha_{1 \mathrm{~B}}$-linked phospholipase-mediated calcium mobilization from the sarcoplasmic reticulum, an intracellular calcium store. Calcium ion influx from the extracellular fluid and mobilized from an intracellular calcium store induces vascular contraction. It is unclear which mechanism contributes more to the hyper-reactive vascular bed in SHR/Izm. In the present study, WB-4101 but not CEC suppressed vascular contraction in SHR/Izm. This finding means that L-type calcium channels predominantly act on the blood vessels of SHR/Izm compared with phospholipase-mediated calcium mobilization from intracellular calcium stores. In addition, our data using caffeine and ryanodine showed that the calcium store in the blood vessels was smaller in SHR/Izm than in WKY/Izm rats.

\section{Conclusion}

In conclusion, $\mathrm{N}$-type calcium channels but not $\mathrm{P} / \mathrm{Q}$-type calcium channels play an important role in the increased sympathetic tone in SHRs. In addition, although $\alpha 1 \mathrm{~A}$-linked L-type calcium channels mainly contribute to the increased vascular tone, the calcium store size was reduced in SHRs.

\section{Acknowledgements}

This study was supported by a Grant-in-Aid for Scientific Research (C) (\#26460915) from the Ministry of Education, Culture, Sports, Science, and Technology (MEXT), Japan.

\section{References}

[1] Nishimura (Hano), T., Nishio, I., Ohtani, H., Jimbo, S., Kuchii, M. and Masuyama, 
Y. (1979) Plasma Catecholamines Determination Using High Pressure Liquid Chromatography and Their Roles in Blood Pressure Regulation and Experimental Hypertension in Rats. Japanese Circulation Journal, 43, 855-865.

https://doi.org/10.1253/jcj.43.855

[2] Masuyama, Y., Nishimura (Hano), T., Nishio, I. and Kuchii, M. (1979) Norepinephrine Clearance in Hypertensive Patients with Various Degrees of Renal Function. Clinical Science, 57, 213s-215s. https://doi.org/10.1042/cs057213s

[3] Hano, T. and Rho, J. (1989) Norepinephrine Overflow in Perfused Mesenteric Arteries of Spontaneously Hypertensive Rats. Hypertension, 14, 44-53. https://doi.org/10.1161/01.HYP.14.1.44

[4] Fujii, S., Kameyama, K., Hosono, M., Hayashi, Y. and Kitamura, K. (1997) Effects of Cilnidipine, a New Dihydropyridine $\mathrm{Ca}^{++}$Channel Antagonist, on N-Type $\mathrm{Ca}^{++}$ Channel in Rat Dorsal Root Ganglion Neurons. Journal of Pharmacology and Experimental Therapeutics, 280, 1184-1191.

[5] Ferrero, J.J., Bartolomé-Martín, D., Torres, M. and Sánchez-Prieto, J. (2013) Potentiation of mGlu7 Receptor-Mediated Glutamate Release at Nerve Terminals Containing $\mathrm{N}$ and $\mathrm{P} / \mathrm{Q}$ Type $\mathrm{Ca}^{2+}$ Channels. Journal of Neuropharmacology, 67, 213 222. https://doi.org/10.1016/j.neuropharm.2012.10.032

[6] Ditting, T., Linz, P., Freisinger, W., Heinlein, S., Reeh, P.W., Fiedler, C., Siegel, K., Scrogin, K.E., Neuhuber, W. and Veelken, R. (2012) Norepinephrine Reduces $\omega$ Conotoxin-Sensitive $\mathrm{Ca}^{2+}$ Currents in Renal Afferent Neurons in Rats. American Journal of Physiology-Renal Physiology, 302, F350-F357. https://doi.org/10.1152/ajprenal.00681.2010

[7] Smith, A.B. and Cunnane, T.C. (1996) Omega-Conotoxin GVIA-Resistant Neurotransmitter Release in Postganglionic Sympathetic Nerve Terminals. Neuroscience, 70, 817-824. https://doi.org/10.1016/S0306-4522(96)83018-1

[8] Fumagalli, L., Pallavicini, M., Budriesi, R., Gobbi, M., Straniero, V., Zagami, M., Chiodini, G., Bolchi, C., Chiarini, A., Micucci, M. and Valoti, E. (2012) Affinity and Activity Profiling of Unichiral 8-Substituted 1, 4-Benzodioxane Analogues of WB4101 Reveals a Potent and Selective $\alpha 1 \mathrm{~B}$-Adrenoceptor Antagonist. European Journal of Medicinal Chemistry, 58, 184-191. https://doi.org/10.1016/j.ejmech.2012.09.049

[9] Lázaro-Suárez, M.L., Gómez-Zamudio, J.H., Gallardo-Ortíz, I.A., Tanoue, A., Tsujimoto, G., Farias-Rodríguez, V.M. and Villalobos-Molina, R. (2005) Chloroethylclonidine Reveals That Alpha (1 A)-Adrenoceptors Mediate Contraction in Aorta of Alpha (1 D)-Adrenoceptor Knockout Mice. Autonomic and Autacoid Pharmacology, 25, 179-183. https://doi.org/10.1111/j.1474-8673.2005.00348.x

[10] Nakanishi S Microscopy (Oxf) (2016) A Spider Toxin, $\omega$-Agatoxin IV A, Binds to Fixed as Well as Living Tissues: Cytochemical Visualization of P/Q-Type Calcium Channels. Microscopy, 65, 337-340. https://doi.org/10.1093/jmicro/dfw013

[11] Beard, N.A., Wei, L. and Dulhunty, A.F. (2009) Control of Muscle Ryanodine rEceptor Calcium Release Channels by Proteins in the Sarcoplasmic Reticulum Lumen. Clinical and Experimental Pharmacology and Physiology, 36, 340-345. https://doi.org/10.1111/j.1440-1681.2008.05094.x

[12] Lv, T., Gong, H.Q. and Liang, P.J. (2014) Caffeine-Induced $\mathrm{Ca}^{2+}$ Oscillations in Type I Horizontal Cells of the Carp Retina and the Contribution of the StoreOperated Ca ${ }^{2+}$ Entry Pathway. PLoS ONE, 9, e100095.

https://doi.org/10.1371/journal.pone.0100095 
Submit or recommend next manuscript to SCIRP and we will provide best service for you:

Accepting pre-submission inquiries through Email, Facebook, LinkedIn, Twitter, etc. A wide selection of journals (inclusive of 9 subjects, more than 200 journals)

Providing 24-hour high-quality service

User-friendly online submission system

Fair and swift peer-review system

Efficient typesetting and proofreading procedure

Display of the result of downloads and visits, as well as the number of cited articles Maximum dissemination of your research work

Submit your manuscript at: http://papersubmission.scirp.org/

Or contact health@scirp.org 